\title{
In vitro antioxidant and apoptotic activity of Lablab purpureus (L.) Sweet isolate and hydrolysates
}

\author{
Shivon SIPAHLI ${ }^{1 *}$ (D), Depika DWARKA ${ }^{1}$, Eric AMONSOU ${ }^{1}$, John MELLEM ${ }^{1}$
}

\begin{abstract}
Cancer is a disease that invades the lives of millions of people each year. Chemotherapy is currently the most effective treatment however resulting in many adverse effects to the human body. Alternative treatments are being explored to overcome this obstacle. Peptides that possess radical scavenging activity and bioactive properties can be advantageous in prevention and treatment of chronic diseases. In this study, Lablab purpureus isolate and its hydrolysates (trypsin, pepsin and alcalase) were analysed for radical scavenging potential (DPPH, ABTS, superoxide radical scavenging and FRAP) and antiproliferative activity. Antiproliferative activity was confirmed with the peptides ability to induce apoptosis (Caspase 3/7 activity and Annexin V-PI). The lowest inhibitory concentrations $\left(\mathrm{IC}_{50}\right.$ ) for DPPH, ABTS and Superoxide radical scavenging ranged between 1.81-4.47, 1.73-2.42 and 1.36-4.41 mg/mL, respectively. FRAP ranged from 19.20 to $21.94 \mathrm{mg} / \mathrm{mL}$. Generally, it is considered that a good antioxidant encompasses antiproliferative potential. Cell lines, A549, MCF-7 and HEK293, treated with pepsin hydrolysate showed $\left(\mathrm{IC}_{50}\right.$ values of $119.6,9.80$ and $13.86 \mu \mathrm{g} / \mathrm{mL}$ ). The isolate and pepsin were chosen for apoptotic studies. The pepsin hydrolysate showed the highest inhibition in the cancerous cell lines (A549 and MCF-7) without greatly effecting normal cells (HEK293), and the isolate was selected for comparative analysis. Annexin V-PI staining showed cells in different stages of apoptosis (cells during early apoptosis; A549, 42\%; MCF-7, 17\%; HEK, 34\%). Caspase 3/7 assay demonstrated that the peptide causes an increase in caspase activity. Peptides have the potential to act as chemo-preventative agents due to their antioxidant and apoptotic abilities.
\end{abstract}

Keywords: Lablab purpureus; apoptosis; antioxidants; caspase activity.

Practical Application: Bioactive peptides derived from the hydrolysis of Lablab purpureus protein induces apoptosis in cancer cells. Peptides can target cancer cells due to its small size thereby allowing it to enter the cell and trigger apoptosis serving as an effective antiproliferative agent capable of inducing apoptosis in cancer cells while leaving healthy cells relatively unharmed.

\section{Introduction}

The World Health Organisation (WHO) reports that cancer cases will rise from 14 million in 2012 to 22 million within two decades (Chalamaiah et al., 2018; Sharma et al., 2020). Chemotherapy is still regarded as the most effective treatment of cancers even though it is costly and has many unavoidable side effects (Chen et al., 2018).

Antioxidants can be described as an agent that can protect cells from the damaging effects caused by free radicals. Free radicals are natural by-products of cell metabolism, aging and environmental factors (Badarinath et al., 2010; Jahanbani et al., 2016). Diets rich in antioxidant have reported to reduce the risk of many developing diseases (Jahanbani et al., 2016; Chen et al., 2018). Legumes with high antioxidant potential like; Phaseolus vulgaris L. (common beans), Glycine max (L.) Merr. Fabaceae (Soybean) and Phaseolus lunatus L. (Lima beans) have been reported to be beneficial in inhibiting cancers (López-Cortez et al., 2016; Guleria et al., 2020).

Cancer can be triggered or catalysed by the presence of free radicals; therefore, antioxidants can be useful in the prevention and treatment of cancer (Athreya \& Xavier, 2017; Chi et al., 2015).
An effective antiproliferative agent should be able to induce apoptosis in cancerous cells while leaving healthy cells relatively unharmed. Apoptosis in multicellular organisms is demarcated as the process of programmed cell death (Wang et al., 2012). Effector caspases (caspase 3/7) are responsible for morphological and biochemical changes during the degradation phase of apoptosis (Brentnall et al., 2013). Alternative treatments from natural sources such as food proteins could provide a better option to induce apoptosis and treat cancer cells efficiently.

Legumes have been regarded as a significant source of plant-based protein, containing between $20-40 \%$ protein in dry weight (Erbersdobler et al., 2017; Lopez-Barrios et al., 2014). Apart from being a cost effective and adaptable crop, in recent years, legumes have been utilised for more than their nutritional benefits (Lopez-Barrios et al., 2014). Legume proteins and peptides have been studied for their effects against chronic diseases such as diabetes, inflammation, hypertension, and cancer (Barnes et al., 2015; Erbersdobler et al., 2017; Korhonen \& Pihlanto, 2006). Numerous reports specify that diets rich in legume crops 
are correlated with lower cancer mortality rates (Duranti, 2006; Sánchez-Chino et al., 2015).

Proteins and peptides from legume sources such as soybean and black Jamapa bean have been reported by Torres-Fuentes et al. (2015), Carrasco-Castilla et al. (2012), to have potent antioxidant capacity. Soybean peptides have been reported to have approximately 3 - 5 times more antioxidant activity as compared to the parent protein (Kamran \& Reddy, 2018). The authors isolated and characterized novel anticancer pentapeptide derived from rice bran hydrolysate. The peptide is resistant to gastrointestinal juices and possess inhibitory properties on colon, breast, lung, and liver cancer cell lines. Peptides are specific protein fragments that are inactive within the sequence of the parent protein (HernándezLedesma \& Hsieh, 2013; Udenigwe \& Aluko, 2012). These peptides can be liberated from the parent proteins by fermentation, food processing and enzyme hydrolysis (Udenigwe \& Aluko, 2012). Girón-Calle et al. (2010) assessed peptides derived from chickpea hydrolysed by pepsin and pancreatin. The hydrolysates inhibited colon and leukemia cell lines.

Lablab purpureus also referred to as hyacinth bean or Lablab is regarded as an adaptable and drought tolerant crop that grows throughout the year. This legume contains between $18-25 \%$ protein (Hossain et al., 2016; Subagio, 2006). Lablab is regarded as a rich source of essential amino acids, particularly lysine and leucine (Hossain et al., 2016). There is continuous interest in peptides for their use as nutraceuticals particularly cancer therapy (Chen et al., 2018). The protein content and under-utilisation of Lablab would make this a suitable source for peptides. Therefore, the aim of this study was to determine the antioxidant effects of $L$. purpureus isolate and hydrolysates. It is generally considered that a good antioxidant encompasses antiproliferative potential. Hence, this study also assessed the antiproliferative effect of the isolate as well as the hydrolysate on cancerous and non-cancerous cell lines.

\section{Materials and methods}

\subsection{Sample preparation}

Lablab purpureus seeds were collected in Durban, Kwazulu Natal, South Africa. Voucher specimens were deposited at the Ward Herbarium, University of KwaZulu Natal, Durban, South Africa. Lablab purpureus seeds were soaked in water (16-20 h), dehulled and dried for $20 \mathrm{~h}$ at $50{ }^{\circ} \mathrm{C}$. Seeds were milled into flour and sieved through a $180 \mu \mathrm{m}$ sieve and then defatted with hexane at a ratio of 1:5 (flour: hexane; w/v). The defatted flour was stored in a cool, dry environment until required for analysis.

\subsection{Protein extraction}

Protein was extracted according to a method by He et al. (2013) with minor modification. Briefly, defatted flour was reconstituted in distilled water $(1: 5 ; \mathrm{w} / \mathrm{v})$, the $\mathrm{pH}$ was adjusted to $\mathrm{pH}$ 10. The solution was stirred for $2 \mathrm{~h}$ at $37^{\circ} \mathrm{C}$ and then centrifuged ( $10000 \mathrm{x} \mathrm{g}$ for $45 \mathrm{~min}$ ). Thereafter the supernatant was adjusted to $\mathrm{pH} 5$ (pellet discarded) and then centrifuged (10 $000 \mathrm{x}$ g for $45 \mathrm{~min}$ ). The supernatant was discarded, and the pellet resuspended in distilled water. Finally, the $\mathrm{pH}$ was adjusted to $\mathrm{pH} 7$ and the protein extract was freeze dried.

\subsection{Preparation of protein hydrolysates}

Protein hydrolysates were prepared using the method by Tang et al. (2009) with some modifications. Three proteases were used; pepsin (Sigma Aldrich - $561 \mathrm{U} / \mathrm{mg}$ ): $37^{\circ} \mathrm{C}$; pH 2, alcalase (Sigma Aldrich - $\geq 0.75 \mathrm{U} / \mathrm{mL}$ ): $50^{\circ} \mathrm{C} ; \mathrm{pH} 8$ and trypsin (Sigma Aldrich - $13000-20000 \mathrm{BAEE} \mathrm{U} / \mathrm{mg}$ ): $37^{\circ} \mathrm{C} ; \mathrm{pH} 8$. The substrate was prepared by reconstituting protein isolates in distilled water $(1: 20 ; \mathrm{w} / \mathrm{v})$. For all reactions, enzymes were added at $5 \%$ of the substrate ratio on dry basis. Each substrate was incubated for $4 \mathrm{~h}$, with the $\mathrm{pH}$ monitored regularly and adjusted when required. Thereafter, the substrate was heated at $100{ }^{\circ} \mathrm{C}$ for $10 \mathrm{~min}$, to stop the reaction, and subsequently cooled on ice to $37^{\circ} \mathrm{C}$ and finally centrifuged (10 $000 \mathrm{x} \mathrm{g}$ for $30 \mathrm{~min}$ ). The supernatant was then freeze dried.

\subsection{SDS-PAGE}

The SDS-PAGE of $L$. purpureus isolate and hydrolysates were analysed according to Invitrogen (2010) under reducing conditions. Novex ${ }^{\mathrm{TM}}$ Bolt Bis-Tris gels were used with the Invitrogen Mini Gel tank under a constant voltage (200 V).

\subsection{Antioxidant potential}

DPPH (2,2-diphenyl-1-picrylhydrazyl) radical scavenging assay

DPPH radical scavenging assay was done according to the method by He et al. (2013) with modifications. Samples were prepared in distilled water containing $1 \%$ triton X-100 $(1-5 \mathrm{mg} / \mathrm{mL})$. Briefly, $100 \mu$ lof DPPH $(100 \mu \mathrm{M})$ was added to $100 \mu \mathrm{L}$ of sample. The 96-well plate was incubated in the dark for $30 \mathrm{~min}$ and the absorbance read at $517 \mathrm{~nm}$. Positive control was glutathione and the blank contained distilled water and DPPH. Scavenging activity was calculated as follows (Formula 1):

Radical Scavenging activity $=\frac{\text { Absorbance }(\text { blank })-\text { Absorbance }(\text { sample })}{\text { Absorbance }(\text { blank })} \times 100$

ABTS (2,2'-azino-bis (3-ethylbenzothiazoline-6-sulphonic acid) radical scavenging assay

The ABTS radical scavenging assay was conducted according to the method by Lee et al. (2015) with modifications. Briefly, $7 \mathrm{mM}$ ABTS and $2.45 \mathrm{mM}$ potassium persulfate were combined in a ratio of 1:1 (v/v) and stirred for 16-20 h under dark conditions. The ABTS stock solution was diluted with $10 \mathrm{mM}$ potassium phosphate buffer ( $\mathrm{pH} 7.4$ ) to an absorbance $(734 \mathrm{~nm}$ ) of $0.700 \pm 0.020$. Thereafter, $100 \mu \mathrm{L}$ ABTS reagent was added to of sample $100 \mu \mathrm{L}(1-5 \mathrm{mg} / \mathrm{mL})$ in a $96-$ well plate and incubated at $30^{\circ} \mathrm{C}$ for $4 \mathrm{~min}$. The absorbance was read at $734 \mathrm{~nm}$. The positive control was glutathione and buffer used as the blank. Scavenging capacity was calculated using the following Formula 2:

Scavenging capacity $=\frac{\text { Absorbance }(\text { blank })-\text { Absorbance }(\text { sample })}{\text { Absorbance }(\text { blank })} \times 100$ 


\section{Superoxide radical scavenging assay}

The superoxide radical scavenging activity was assessed using the method by He et al. (2013) with modifications. The samples and standards (1-5 mg/mL) were prepared in 0.1 $\mathrm{M} \mathrm{NaOH}$. Briefly, $80 \mu \mathrm{L}$ of $50 \mathrm{mM}$ Tris- $\mathrm{HCl}(\mathrm{pH} 8.3)$ containing $1 \mathrm{mM}$ EDTA was added to $80 \mu \mathrm{L}$ of sample. Thereafter, $40 \mu \mathrm{L}$ of $1.5 \mathrm{mM}$ pyrogallol prepared in $10 \mathrm{mM} \mathrm{HCl}$ was added. Absorbance was read at $420 \mathrm{~nm}$ within $4 \mathrm{~min}$. The positive control was glutathione and $50 \mathrm{mM}$ Tris- $\mathrm{HCl}$ was the blank. Scavenging capacity was calculated using the following Formula 3:

Superoxide radical scavenging activty $(\%)=\frac{\Delta A b s_{\text {control }}-\Delta A b s_{\text {sample }}}{\Delta A b s_{\text {control }}} \times 100$

\section{Ferric Reducing Ability of Plasma (FRAP) assay}

The FRAP assay was conducted according to the method by Benzie \& Strain (1996) with modifications. The FRAP reagent was prepared by combining $300 \mathrm{mM}$ acetate buffer, $10 \mathrm{mM}$ TPTZ prepared in $40 \mathrm{mM} \mathrm{HCl}$ and $20 \mathrm{mM}$ ferrous chloride in a ratio of 10:1:1 (v/v/v). Briefly, $3 \mathrm{~mL}$ of FRAP reagent was added to $100 \mu \mathrm{L}$ of sample (1-5 mg/mL) and incubated at $37{ }^{\circ} \mathrm{C}$ for $4 \mathrm{~min}$. The absorbance was read at $593 \mathrm{~nm}$ at 0 and 4 minutes. The FRAP value was determined by an iron sulphate standard curve with glutathione as the positive control.

\subsection{Cell culture}

The cells (human embryonic kidney (A549 - P10), breast cancer (MCF-7 - P9) and human lung cancer (HEK293 - P10) were obtained from the Department of Human Physiology at the University of KwaZulu-Natal, Westville campus. The cells were grown at $37^{\circ} \mathrm{C}, 5 \% \mathrm{CO}_{2}$ in Dulbecco's modified Eagle's medium (DMEM) containing 10\% foetal bovine serum (FBS) and antibiotics (penicillin; $10000 \mathrm{U} / \mathrm{mL}$ and streptomycin sulphate; $10000 \mathrm{U} / \mathrm{mL})$.

\section{Cytotoxicity}

Cytotoxicity was determined by the 3-(4,5 dimethylthiazol2-yl)-2,5-diphenyltetrazolium bromide (MTT) assay was conducted according to Dwarka et al. (2017). Briefly, Cells $\left(1 \times 10^{2}\right.$ cells $\left./ \mathrm{mL}\right) 50 \mu \mathrm{L}$ DMEM were seeded in 96-well flat bottom plate and incubated for $24 \mathrm{~h}$ at $37^{\circ} \mathrm{C}, 5 \% \mathrm{CO}_{2}$. Cells were then treated with $50 \mu \mathrm{L}$ of isolate and hydrolysates prepared in 5\% DMSO (1000-7.8 ug/mL) and incubated for $24 \mathrm{~h}$. Camptothecin the positive control while the negative control contained untreated cells. A $20 \mu \mathrm{L}$ aliquot of MTT $(5 \mathrm{mg} / \mathrm{mL})$ solution prepared in PBS was added to the cells and incubated for $4 \mathrm{~h}$ at $37^{\circ} \mathrm{C}$. Finally, $100 \mu \mathrm{L}$ of DMSO was added to solubilise the formazan salt formed. The absorbance was read at $570 \mathrm{~nm}$ on a microplate spectrophotometer (Multiscan Go, Thermo Scientific). The percentage viability was determined using the following formula:

$\%$ Cell viability $=\frac{\text { Absorbance of treated cells }}{\text { Absorbance of untreated cells }} \times 100$

\section{Annexin V-PI}

The FITC Annexin V apoptosis detection kit II (BD Bioscience) assay was conducted according to the manufacturer's specifications. Briefly, cells were seeded in 24-well flat bottom plate $\left(1 \times 10^{6}\right.$ cells $\left./ \mathrm{mL}\right)$ incubated overnight to adhere. Cells were then treated with $100 \mu \mathrm{l}$ of isolate $\left(\mathrm{IC}_{50}\right.$ of 255.0, 31.5 and 49.0 for A549, MCF-7 and HEK293 respectively and pepsin ( IC $_{50}$ of 119.6, 9.8 and 13.9) for each of the cell lines respectively. Camptothecin was used as the positive control. After $24 \mathrm{~h}$, cells were trypsinised and centrifuged to obtain a pellet. Cells were then resuspended in $100 \mu \mathrm{l}$ of $1 \mathrm{x}$ binding buffer. Thereafter, $5 \mu \mathrm{L}$ of FITC Annexin V and $5 \mu \mathrm{l}$ PI was added and incubated for $15 \mathrm{~min}$ at $25^{\circ} \mathrm{C}$ in a dark environment. Finally, $400 \mu \mathrm{L}$ of $1 \mathrm{X}$ Binding buffer was added. Samples were analysed by flow cytometry (BD FACSAria II, BD Bioscience) within $1 \mathrm{~h}$.

\section{Caspase-Glo 3/7 assay}

The Caspase-Glo 3/7 kit (Promega Corporation (2019) Cat no. G8090) was used to determine the presence of caspase 3/7. The assay was conducted according to manufacturer's protocol. Cells were seeded $\left(1 \times 10^{2}\right.$ cells $\left./ \mathrm{mL}\right)$ and incubated for $24 \mathrm{~h}$. Cells were then treated with isolate $\left(\mathrm{IC}_{50}\right.$ of 255.0, 31.5 and 49.0 for A549, MCF-7 and HEK293 respectively and pepsin ( $\mathrm{IC}_{50}$ of $119.6,9.8$ and 13.9) for each of the cell lines respectively). For the reaction, $100 \mu \mathrm{l}$ of Caspase-Glo reagent was added and incubated for $1 \mathrm{~h}$. The blank contained 5\% DMSO and DMEM while the negative control contained treated cells and the positive control was camptothecin. Samples were analysed using a fluorescence spectrophotometer (GloMax).

\subsection{Statistical analysis}

Results were analysed by ANOVA (Graph Pad Prism software, San Diego, CA, USA). All analysis was done in triplicate, mean \pm standard deviation was calculated. $\mathrm{IC}_{50}$ was also calculated using Graph Pad Prism. The lower the $\mathrm{IC}_{50}$ concentration on the cancerous cells, the more potent the isolate as a therapeutic.

\section{Results and discussion}

\subsection{SDS-PAGE}

L. purpureus isolate and hydrolysates ranged between 198 and $14 \mathrm{kDa}$ (Figure 1). The SDS-PAGE proves that samples were hydrolysed. Naiker et al. (2019) assessed L. purpureus isolates. The authors reported bands between 200 and $24 \mathrm{kDa}$ with dominant bands at approximately $55 \mathrm{kDA}$.

\subsection{Antioxidant activity}

The inhibitory concentration $\left(\mathrm{IC}_{50}\right)$ of DPPH, ABTS and superoxide radical scavenging activities of $L$. purpureus isolate and hydrolysate are shown in Table $1 . \mathrm{IC}_{50}$ values indicate the lowest inhibitory concentration of the samples.

The DPPH radical scavenging activity showed that the isolate has the lowest $\mathrm{IC}_{50}(1.81 \mathrm{mg} / \mathrm{mL})$ which was significantly different $(\mathrm{p}<0.05)$ to the hydrolysates. Glutathione, a known antioxidant 
was 1.8-fold greater than the isolate. $\mathrm{IC}_{50}$ of hydrolysates ranged between $2.76-4.47 \mathrm{mg} / \mathrm{mL}$. L. purpureus isolate was similar in comparison with radical scavenging activity of soybean protein $\left(\mathrm{IC}_{50} 2.11 \mathrm{mg} / \mathrm{mL}\right.$ ) and mung bean protein ( $\mathrm{IC}_{50} 1.47 \mathrm{mg} / \mathrm{mL}$ ) (Chen et al., 2017). The DPPH assay favoured the isolate which contradicts most studies that have found that hydrolysates have higher antioxidant activity while the ABTS assay showed greater activity in the hydrolysates (Ramkisson et al., 2020; Singh, 2011). This could be attributed to the mechanisms employed by each assay. Therefore, their radical scavenging capabilities could be different (Thumbrain et al., 2020).

The ABTS radical scavenging activity resulted in $\mathrm{IC}_{50}$ for L. purpureus isolate and hydrolysates ranged from $1.73-2.42 \mathrm{mg} / \mathrm{mL}$. The pepsin and alcalase hydrolysates had higher activity with $\mathrm{IC}_{50}$ values of $1.73 \mathrm{mg} / \mathrm{mL}$ and $1.72 \mathrm{mg} / \mathrm{mL}$ respectively, as

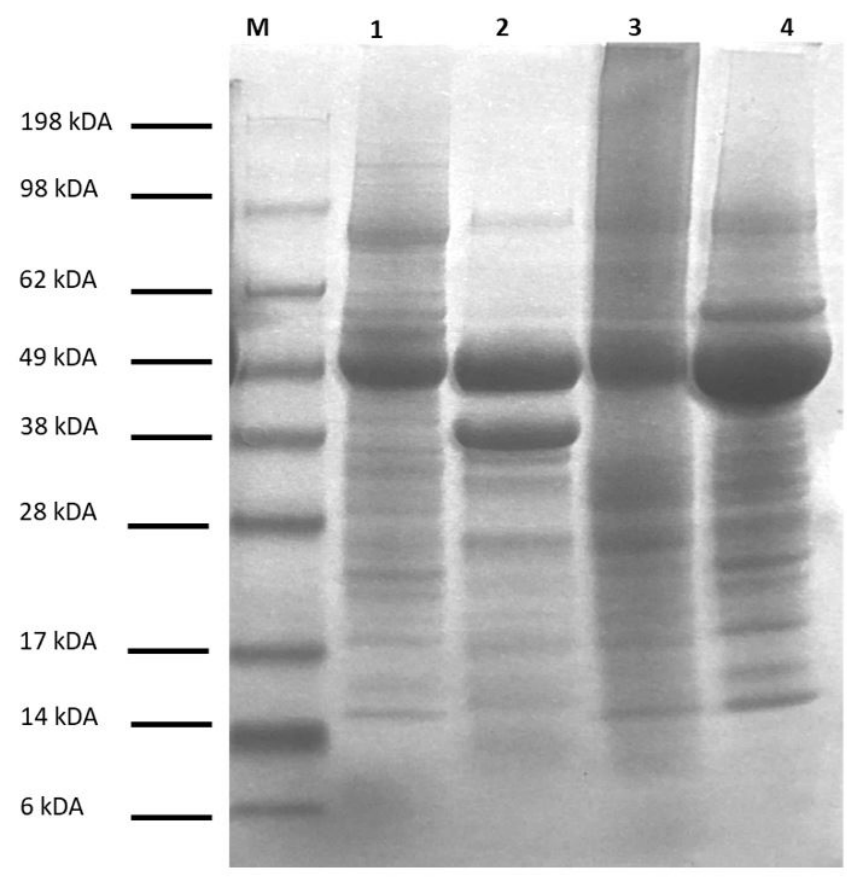

Figure 1. SDS-PAGE of L. purpureus isolate and hydrolsates under reducing conditions. Lane M - Molecular weight marker, 1 - Isolate, 2 Pepsin hydrolysate, 3 - Trypsin hydrolysate and 4 - Alcalase hydrolysate.

Table 1. Radical scavenging activity $\left(\mathrm{IC}_{50}\right)$ of Lablab purpureus isolate and hydrolysates as determined by DPPH, ABTS and Superoxide radical scavenging activity.

\begin{tabular}{cccc}
\hline Sample & $\begin{array}{c}\text { DPPH radical } \\
\text { scavenging } \\
\text { activity IC }_{50} \\
(\mathrm{mg} / \mathrm{mL})\end{array}$ & $\begin{array}{c}\text { ABTS radical } \\
\text { scavenging } \\
\text { activity IC } \\
(\mathrm{mg} / \mathrm{mL})\end{array}$ & $\begin{array}{c}\text { Superoxide } \\
\text { radical } \\
\text { scavenging } \mathrm{IC}_{50} \\
(\mathrm{mg} / \mathrm{mL})\end{array}$ \\
\hline Isolate & $1.81^{\mathrm{b}} \pm 2.94$ & $2.03^{\mathrm{e}} \pm 1.75$ & $3.17^{\mathrm{ab}} \pm 1.09$ \\
Trypsin & $4.47^{\mathrm{de}} \pm 0.14$ & $2.42^{\mathrm{d}} \pm 2.41$ & $3.79^{\mathrm{ab}} \pm 0.83$ \\
Pepsin & $2.76^{\mathrm{e}} \pm 0.14$ & $1.73^{\mathrm{cd}} \pm 0.50$ & $4.51^{\mathrm{ab}} \pm 0.56$ \\
Alcalase & $3.81^{\mathrm{ce}} \pm 0.29$ & $1.82^{\mathrm{b}} \pm 0.39$ & $1.36^{\mathrm{ab}} \pm 0.81$ \\
Glutathione & $0.98^{\mathrm{a}} \pm 1.08$ & $6.44^{\mathrm{a}} \pm 0.35$ & $2.74^{\mathrm{b}} \pm 0.30$ \\
\hline
\end{tabular}

Data represents mean $\pm S D(n=3)$. Values with different superscript are significantly different $(\mathrm{p}<0.05)$. compared to the isolate $\left(\mathrm{IC}_{50} 2.03 \mathrm{mg} / \mathrm{mL}\right.$ ). When compared to glutathione, the samples showed greater antioxidant potential (2.6-3.7-fold greater). Similar findings were reported by a study conducted on Bambara groundnut (Arise et al., 2017) and Okra (Sbroggio et al., 2016).

The $\mathrm{IC}_{50}$ values corresponding with the superoxide radical scavenging activity ranged between 1.36 and $4.51 \mathrm{mg} / \mathrm{mL}$. Alcalase was significantly $(\mathrm{p}<0.05)$ more potent against the superoxide radical $\left(\mathrm{IC}_{50} 1.36 \mathrm{mg} / \mathrm{mL}\right)$. Glutathione had significantly lower antioxidant activity $\left(\mathrm{IC}_{50} 2.74 \mathrm{mg} / \mathrm{mg}\right)$ when compared with the alcalase hydrolysate indicating that the hydrolysate has good antioxidant potential. Higher peptide chain lengths can result in lower antioxidant activity making them less effective in scavenging the ABTS radical (Ramkisson et al., 2020).

The FRAP assay showed no significant $(\mathrm{p}<0.05)$ difference between the isolate and hydrolysates (Table 2). Results ranged between 19.20 and $21.94 \mathrm{mg} / \mathrm{mL}$. Lower activity was reported for pigeon pea (Sekhon et al., 2017), lentil, pea, and cowpea (Marathe et al., 2011). A strong reducing power of protein hydrolysate could be attributed to the increase in available hydrogen ions because of the breaking of peptide bonds (Sbroggio et al., 2016).

Antioxidant activity is generally used for preliminary screening of bioactivity. Overall, the isolate and hydrolysates proved to be good antioxidants as they possessed activity comparable to glutathione.

\subsection{Cytotoxicity}

The MTT colorimetric assay was conducted to assess whether L. purpureus isolate and hydrolysates had the ability to inhibit the proliferation of cancerous cell lines A459 and MCF-7 and healthy cells HEK293 (Figure 2). A549 cells treated with pepsin hydrolysate had the lowest $\mathrm{IC}_{50}$ of $119.60 \mu \mathrm{g} / \mathrm{mL}$ which was 2.5 -fold greater than camptothecin, a chemo-preventative agent. Cell viability of pepsin and camptothecin treated at a concentration of $125 \mu \mathrm{g} / \mathrm{mL}$ was $48.37 \%$ and $57.11 \%$ respectively. MCF-7 cells treated with pepsin had the lowest $\mathrm{IC}_{50}$ of $9.8 \mu \mathrm{g} / \mathrm{mL}$ while the isolate had the highest $\mathrm{IC}_{50}$ of $31.54 \mu \mathrm{g} / \mathrm{mL}$. Cell viability respectively was $55.34 \%$ and $51.56 \%$ at a concentration of $31.25 \mu \mathrm{g} / \mathrm{mL}$. Peptides had lower IC $_{50}$ values in MCF-7 treated cells suggesting sensitivity in these cells as compared A549 and HEK293 (Fan et al., 2016; Khangebam \& Chakrabarti, 2018). HEK293 cells treated with Pepsin had the lowest $\mathrm{IC}_{50}$ of $13.86 \mu \mathrm{g} / \mathrm{ml}$. Cell viability of pepsin ranged between 62.77 and $91.65 \%$ across the concentrations.

Table 2. Ferric reducing ability of Lablab purpureus isolate and hydrolysates as determined by FRAP.

\begin{tabular}{cc}
\hline Sample & $\mathrm{mM} \mathrm{FeSO}_{4} / \mathrm{mg}^{\mathrm{a}}$ protein \\
\hline Isolate & $19.20^{\mathrm{ab}} \pm 5.49$ \\
Trypsin & $20.57^{\mathrm{ab}} \pm 4.11$ \\
Pepsin & $21.94^{\mathrm{ab}} \pm 3.88$ \\
Alcalase & $27.43^{\mathrm{ab}} \pm 3.88$ \\
Glutathione & $855.71^{\mathrm{b}} \pm 24.68$ \\
\hline
\end{tabular}

Data represents mean $\pm S D(n=3)$. Values with different superscript are significantly different $(\mathrm{p}<0.05)$. 

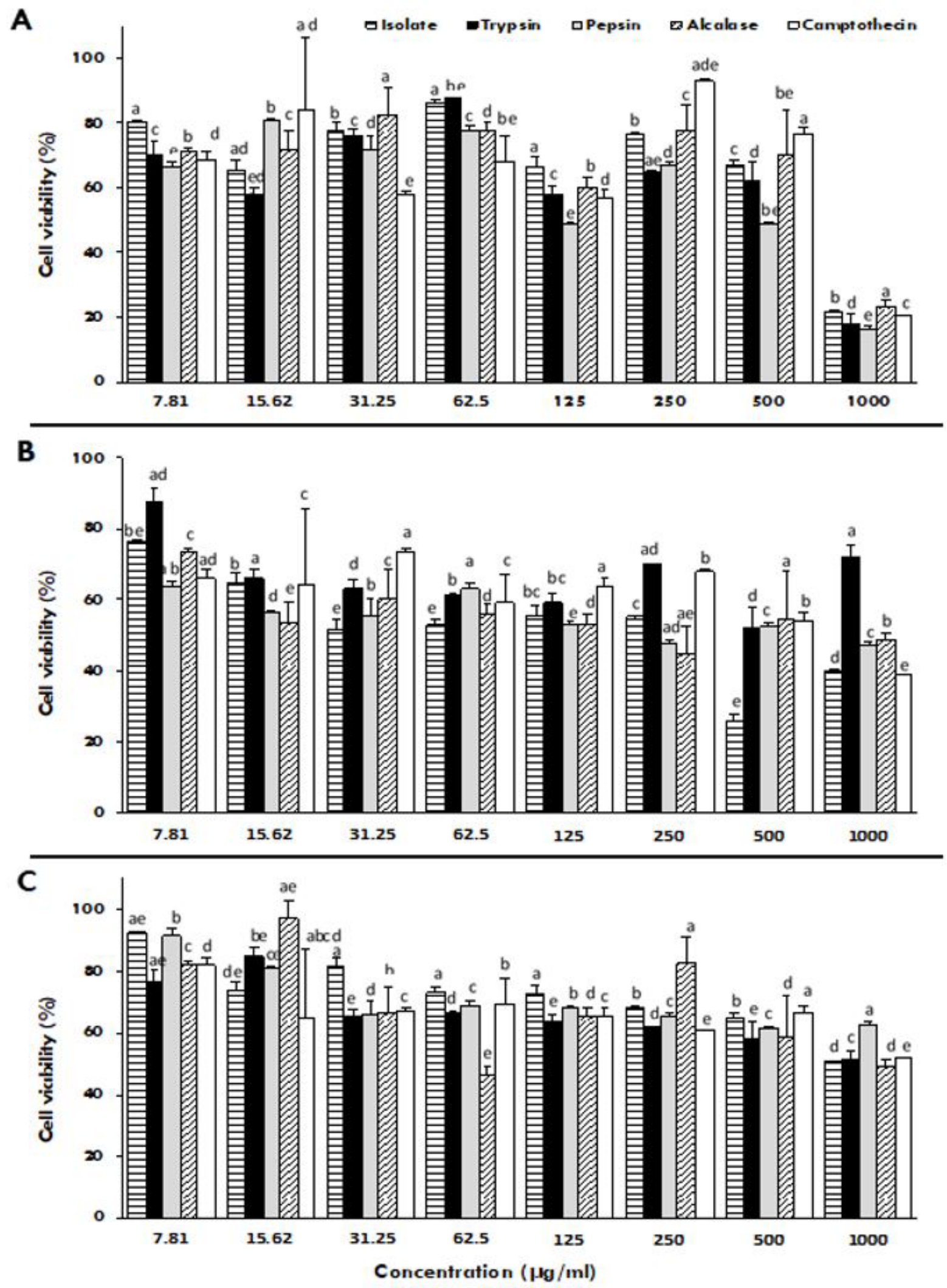

Figure 2. Cell viability of A549 [A], MCF-7 [B] and HEK293 [C] cell lines treated with Lablab purpureus isolate and hydrolysates as determined by MTT cytotoxicity assay. Data represents mean \pm SD $(n=3)$. Values with different superscript are significantly different $(\mathrm{p}<0.05)$. 
Cell viability of the cancerous cell lines were lower than that of the healthy cell line. The isolate and pepsin hydrolysate were chosen for apoptotic studies as the pepsin hydrolysate showed the highest inhibition in the cancerous cell lines (A549 and MCF-7) while not effecting normal cells (HEK293) immensely, with the isolate selected for comparative analysis.

\section{Quantification of apoptosis}

Annexin V-PI staining separates cells according to stages of apoptosis i.e. living cells or healthy (Q4), dying or early apoptotic cells (Q3) and dead or late apoptotic (Q2) and necrotic cells (Q1) (Sabbione et al., 2019). Assessment of early apoptosis in A549 cell treated with the isolate (26.4\%) and pepsin (41.5\%) could be compared with camptothecin (31.6\%). MCF-7 cells that were treated with the isolate and pepsin showed 33.4 and $17.4 \%$, respectively, in early apoptosis while late apoptosis showed 18.4 and $17.9 \%$ (Figure 3). Overall, the pepsin hydrolysate was more effective in initiating apoptosis in cancerous cell lines. In a study by (Fan et al., 2016) reported 13\% and 18.2\% of MCF-7 cells treated with a peptide conjugated with a viral protein were in late apoptosis. The isolate and pepsin treated HEK293 cells showed healthy cells of 77.2 and $64 \%$ as depicted in Figure 3. Studies by Dia \& de Mejia (2011), Dia \& Gonzalez de Mejia (2010), McConnell et al. (2015) showed that anticancer activities of different peptides induce pro-apoptotic activity on selected cell lines.

Induction of apoptosis was also evaluated by measuring caspase 3/7 activation (Figure 4 ). Cell viability is indirectly proportional to fluorescence units (FU) (Butterick et al., 2014). HEK293 treated cells showed the greatest fluorescence units, this result is largely due to cells undergoing stress during transportation for analysis. Cancerous cell lines are hardier than healthy cells which are very sensitive to environmental changes. The cell lines treated with pepsin hydrolysate showed no significant difference $(\mathrm{p}<0.05)$ when compared with camptothecin. Thereby confirming that the pepsin hydrolysate is inducing apoptosis. These results are supported by Annexin V-PI. Burz et al. (2009) confirmed that bioactive peptides exert anti-tumor activity via apoptosis induction which involves the activation of specific caspases. Studies on whey isolates and fractions (Castro et al., 2009) and

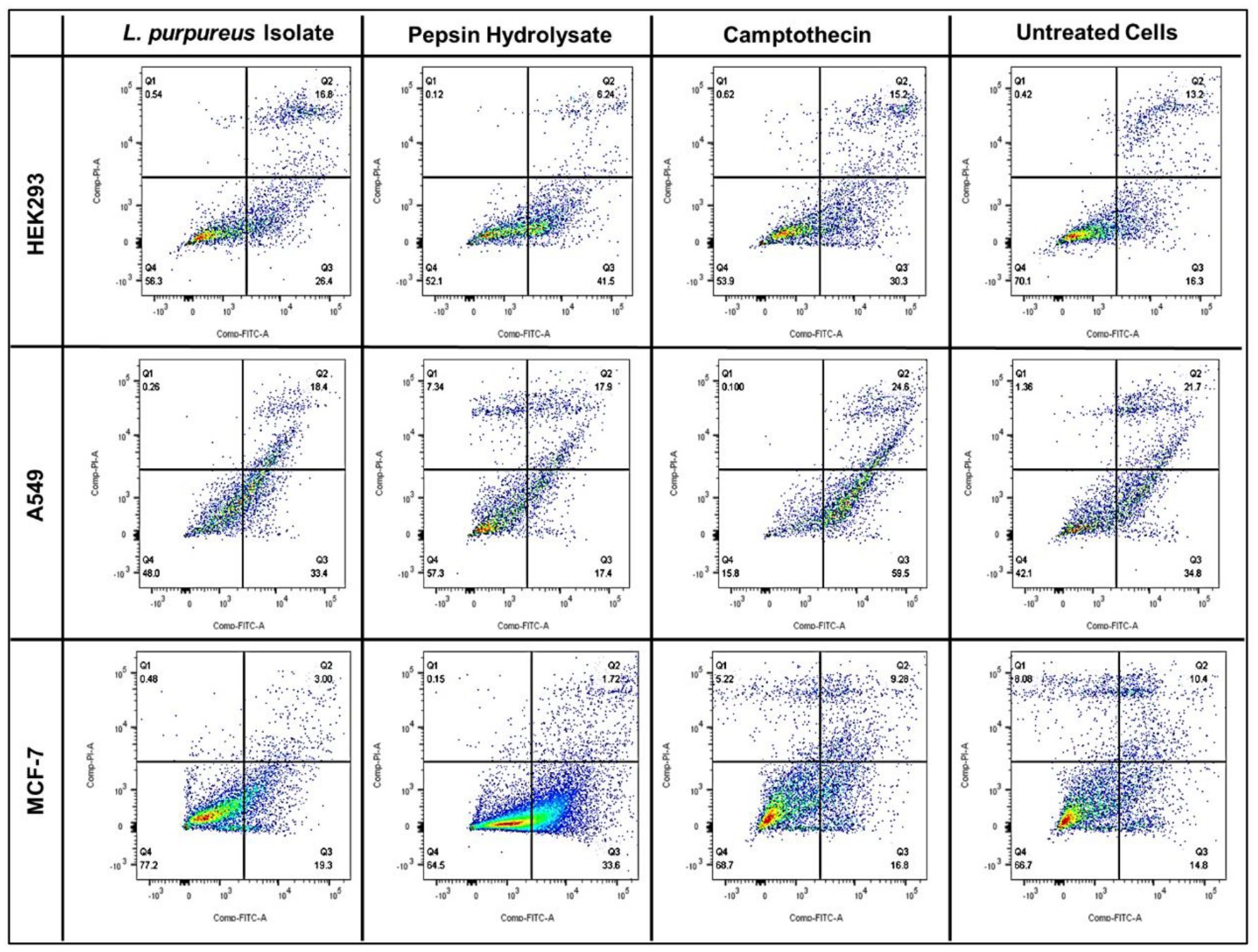

Figure 3. Flow cytometry analysis showing the externalisation of phosphatidylserine in A549, MCF-7 and HEK293 cells treated with Lablab purpureus isolate, pepsin hydrolysate, Camptothecin and untreated cells at $\mathrm{IC}_{50}$ values determined by the MTT assay. 


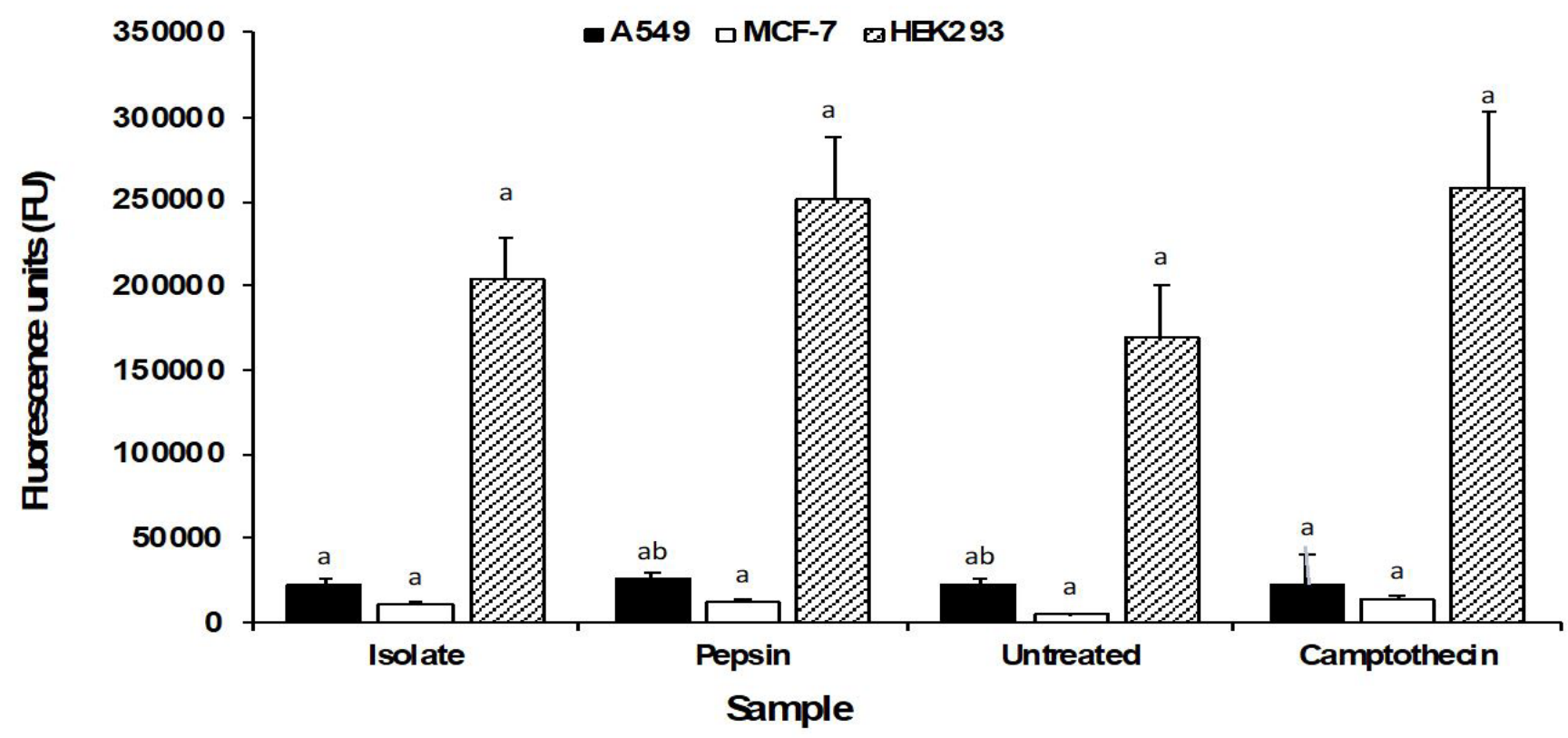

Figure 4. Caspase 3/7 activity measured as fluorescence units emitted by the cleavage of peptide DEVD. Cell lines, A549, MCF-7 and HEK293 were treated with Lablab purpureus isolate and pepsin hydrolysate at $\mathrm{IC}_{50}$ values obtained by MTT assay. Camptothecin was the positive control and untreated cells the negative control. Data represents mean \pm SD. Values with different superscript are significantly different $(\mathrm{p}<0.05)$.

amaranth proteins (Sabbione et al., 2019) both showed higher caspase 3 activity compared to the control.

\section{Conclusion}

Peptides have attracted attention as drug candidates for cancer therapy because they offer certain key advantages over alternative molecules. In contrast to traditional drugs, peptides have high affinity, strong specificity, low toxicity, and adequate tissue penetration. This study showed that protein isolates and hydrolysates from L. purpureus had positive antioxidant potential especially when compared to glutathione, a known antioxidant.

As a potential chemo-preventative agent, the isolate and pepsin hydrolysate, exhibited the best antiproliferative activity at the lowest concentrations. Results were confirmed by apoptotic studies (Annexin V-PI and Caspase 3/7 analysis). Further research must be performed to determine the peptides that provide the antiproliferative effects.

\section{References}

Arise, A., Alashi, A., Nwachukwu, I., Malomo, S., Aluko, R., \& Amonsou, E. (2017). Inhibitory properties of bambara groundnut protein hydrolysate and peptide fractions against angiotensin-converting enzymes, renin and free radicals. Journal of the Science of Food and Agriculture, 97(9), 2834-2841. http://dx.doi.org/10.1002/jsfa.8112. PMid:27786357.

Athreya, A.K., \& Xavier, M. F. (2017). Antioxidants in the treatment of cancer. Nutrition and Cancer, 69(8), 1099-1104. http://dx.doi.or g/10.1080/01635581.2017.1362445. PMid:29043851.

Badarinath, A. V., Rao, K. M., Chetty, C. M. S., Ramkanth, S., Rajan, T. V. S., \& Gnanaprakash, K. (2010). A review on in-vitro antioxidant methods: comparisions, correlations and considerations. International Journal of Pharm Tech Research, 2, 1276-1285.
Barnes, M., Uruakpa, F., \& Udenigwe, C. (2015). Influence of cowpea (Vigna unguiculata) peptides on insulin resistance. Journal of Nutritional Health \& Food Science, 3, 1-3.

Benzie, I., \& Strain, J. J. (1996). The ferric reducing ability of plasma (FRAP) as a measure of "antioxidant power": the FRAP assay. Analytical Biochemistry, 239(1), 70-6. http://dx.doi.org/10.1006/ abio.1996.0292. PMid:8660627.

Brentnall, M., Rodriguez-Menocal, L., De Guevara, R., Cepero, E., \& Boise, L. H. (2013). Caspase-9, Caspase-3 and Caspase-7 have distinct roles during intrinsic apoptosis. BMC Cell Biology, 14, 32. http://dx.doi. org/10.1186/1471-2121-14-32. PMid:23834359.

Burz, C., Berindan-Neagoe, I., Balacescu, O., \& Irimie, A. (2009). Apoptosis in cancer: Key molecular signaling pathways and therapy targets. Acta Oncologica, 48(6), 811-821. http://dx.doi. org/10.1080/02841860902974175. PMid:19513886.

Butterick, T., Duffy, C., Lee, R., Billington, C., Kotz, C., \& Nixon, J. (2014). Use of a Caspase multiplexing assay to determine apoptosis in a hypothalamic cell model. Journal of Visualized Experiments, 86, 51305. http://dx.doi.org/10.3791/51305. PMid:24797379.

Carrasco-Castilla, J., Hernández-Álvarez, A. J., Jiménez-Martínez, C., JacintoHernández, C., Alaiz, M., Girón-Calle, J., Vioque, J., \& Dávila-Ortiz, G. (2012). Antioxidant and metal chelating activities of peptide fractions from phaseolin and bean protein hydrolysates. Food Chemistry, 135(3), 17891795. http://dx.doi.org/10.1016/j.foodchem.2012.06.016. PMid:22953924.

Castro, G. A., Maria, D. A., Bouhallab, S., \& Sgarbieri, V. C. (2009). In vitro impact of a whey protein isolate (WPI) and collagen hydrolysates (CHS) on B16F10 melanoma cells proliferation. Journal of Dermatological Science, 56(1), 51-57. http://dx.doi.org/10.1016/j. jdermsci.2009.06.016. PMid:19695839.

Chalamaiah, M., Yu, W., \& Wu, J. (2018). Immunomodulatory and anticancer protein hydrolysates (peptides) from food proteins: A review. Food Chemistry, 245, 205-222. http://dx.doi.org/10.1016/j. foodchem.2017.10.087. PMid:29287362. 
Chen, Z., Li, W., Santhanam, R. K., Wang, C., Gao, X., Chen, Y., Wang, C., Xu, L., \& Chen, H. (2018). Bioactive peptide with antioxidant and anticancer activities from black soybean [Glycine max (L.) Merr.] byproduct: Isolation, identification and molecular docking study. European Food Research and Technology

Chen, Z., Wang, J., Liu, W., \& Chen, H. (2017). Physicochemical characterization, antioxidant and anticancer activities of proteins from four legume species. Journal of Food Science and Technology, 54(4), 964-972. http://dx.doi.org/10.1007/s13197-016-2390-x. PMid:28303047.

Chi, C., Hu, F., Wang, B., Li, T., \& Ding, G. (2015). Antioxidant and anticancer peptides from the protein hydrolysate of blood clam (Tegillarca granosa) muscle. Journal of Functional Foods, 15, 301313. http://dx.doi.org/10.1016/j.jff.2015.03.045.

Dia, V. P., \& de Mejia, E. G. (2011). Lunasin induces apoptosis and modifies the expression of genes associated with extracellular matrix and cell adhesion in human metastatic colon cancer cells. Molecular Nutrition \& Food Research, 55(4), 623-634. http://dx.doi. org/10.1002/mnfr.201000419. PMid:21462330.

Dia, V. P., \& Gonzalez de Mejia, E. (2010). Lunasin promotes apoptosis in human colon cancer cells by mitochondrial pathway activation and induction of nuclear clusterin expression. Cancer Letters, 295(1), 44-53. http://dx.doi.org/10.1016/j.canlet.2010.02.010. PMid:20206442.

Duranti, M. (2006). Grain legume proteins and nutraceutical properties. Fitoterapia, 77(2), 67-82. http://dx.doi.org/10.1016/j.fitote.2005.11.008. PMid:16406359.

Dwarka, D., Thaver, V., Naidu, M., Koorbanally, N., \& Baijnath, H. (2017). In vitro chem-preventative activity of Stelitzia nicolai aril extract containing bilirubin. African Journal of Traditional, Complementary, and Alternative Medicines, 14(3), 147-156. http:// dx.doi.org/10.21010/ajtcam.v14i3.16. PMid:28480426.

Erbersdobler, H. F., Barth, C. A. \& Jahreis, G. (2017). Legumes in human nutrition: nutrient content and protein quality of pulses. Ernaehrungs Umschau International, 64(9), 134-135. http://dx.doi. org/10.4455/eu.2017.034.

Fan, L. Q., Du, G., Li, P., Li, M., Sun, Y., \& Zhao, L. (2016). Improved breast cancer cell-specific intracellular drug delivery and therapeutic efficacy by coupling decoration with cell penetrating peptide and Sp90 peptide. Biomedicine and Pharmacotherapy, 84, 1783-1791. http://dx.doi.org/10.1016/j.biopha.2016.10.102. PMid:27899251.

Girón-Calle, J., Alaiz, M., \& Vioque, J. (2010). Effect of chickpea protein hydrolysates on cell proliferation and in vitro bioavailability. Food Research International, 43(5), 1365-1370. http://dx.doi.org/10.1016/j. foodres.2010.03.020.

Guleria, P., Kumar, V., \& Lichtfouse, E. (2020). Sustainable agriculture reviews. Switzerland: Springer.

He, R., Girgih, A., Malomo, S., Ju, X., \& Aluko, R. (2013). Antioxidant activities of enzymatic rapeseed protein hydrolysates and the membrane ultrafiltration fractions. Journal of Functional Foods, 5(1), 219-227. http://dx.doi.org/10.1016/j.jff.2012.10.008.

Hernández-Ledesma, B., \& Hsieh, C. (Eds.) (2013). Bioactive food peptides in health and disease. Rijeka, Croatia: Intech. http://dx.doi. org/10.5772/3318.

Hossain, S., Ahmed, R., Bhowmick, S., Mamun, A. A., \& Hashimoto, M. (2016). Proximate composition and fatty acid analysis of Lablab purpureus (L.) legume seed: Implicates to both protein and essential fatty acid supplementation. SpringerPlus, 5(1), 5. http://dx.doi. org/10.1186/s40064-016-3587-1. PMid:27843756.

Invitrogen. (2010). Novex ${ }^{\oplus}$ pre-cast gel electrophoresis guide. Califórnia: Invitrogen.
Jahanbani, R., Ghaffari, S. M., Salami, M., Vahdati, K., Sepehri, H., Sarvestani, N. N., Sheibani, N., \& Moosavi-Movahedi, A. A. (2016). Antioxidant and anticancer activities of walnut (Juglans regia L.) protein hydrolysates using different proteases. Plant Foods for Human Nutrition (Dordrecht, Netherlands), 71(4), 402-409. http://dx.doi. org/10.1007/s11130-016-0576-z. PMid:27679440.

Kamran, F., \& Reddy, N. (2018). Bioactive peptides from legumes: Functional and nutraceutical potential. Recent Advances In Food Science, 1, 134-149.

Khangebam, B., \& Chakrabarti, R. (2018). Viscera of Labeo Rohita: A potential source of trypsin for industrial application. Journal of Aquatic Food Product Technology, •••, 27.

Korhonen, H., \& Pihlanto, A. (2006). Bioactive peptides: Production and functionality. International Dairy Journal, 16(9), 945-960. http:// dx.doi.org/10.1016/j.idairyj.2005.10.012.

Lee, K.J., Oh, Y., Cho, W., \& Ma, J. (2015). Antioxidant and antiinflammatory activity determination of one hundred kinds of pure chemical compounds using offline and online screening hplc assay. Evidence-Based Complementary and Alternative Medicine, 2015, 165457. http://dx.doi.org/10.1155/2015/165457. PMid:26504472.

Lopez-Barrios, L., Gutierrez-Uribe, J. A., \& Serna-Saldıvar, S. O. (2014). Bioactive peptides and hydrolysates from pulses and their potential use as functional ingredients. Journal of Food Science, 79(3), R273-R283. http://dx.doi.org/10.1111/1750-3841.12365. PMid:24547749.

López-Cortez, M. S., Rosales-Martínez, P., Arellano-Cárdenas, S., \& Cornejo-Mazón, M. (2016). Antioxidants properties and effect of processing methods on bioactive compounds of legumes. In A. K. Goyal (Ed.), Grain legumes. London: Intechopen. http://dx.doi. org/10.5772/63757.

Marathe, S. A., Rajalakshmi, V., Jamdar, S. N., \& Sharma, A. (2011). Comparative study on antioxidant activity of different varieties of commonly consumed legumes in India. Food and Chemical Toxicology, 49(9), 2005-2012. http://dx.doi.org/10.1016/j.fct.2011.04.039. PMid:21601612.

McConnell, E. J., Devapatla, B., Yaddanapudi, K., \& Davis, K. R. (2015). The soybean-derived peptide lunasin inhibits non-small cell lung cancer cell proliferation by suppressing phosphorylation of the retinoblastoma protein. Oncotarget, 6(7), 4649-4662. http://dx.doi. org/10.18632/oncotarget.3080. PMid:25609198.

Naiker, T. S., Baijnath, H., Amonsou, E. O. \& Mellem, J. J. (2019). Effect of steaming and dehydration on the nutritional quality and functional properties of protein isolates produced from Lablab purpureus (L.) Sweet (hyacinth bean). Journal of Food Processing and Preservation, 44(2). http://dx.doi.org/10.1111/jfpp.14334.

Ramkisson, S., Dwarka, D., Venter, S. \& Mellem, J. J. (2020). In vitro anticancer and antioxidant potential of amaranthus cruentus protein and its hydrolysates. Food Science and Technology, 40(suppl. 2), 634639. https://doi.org/10.1590/fst.36219.

Sabbione, A., Ogutu, F., Scilingo, A., Zhang, M., Añón, M., \& Mu, T. (2019). Antiproliferative effect of amaranth proteins and peptides on HT-29 human colon tumor cell line. Plant Foods for Human Nutrition, 74, 107-114. http://dx.doi.org/10.1007/s11130-018-0708-8.

Sánchez-Chino, X., Jiménez-Martínez, C., Dávila-Ortiz, G., ÁlvarezGonzález, I., \& Madrigal-Bujaidar, E. (2015). Nutrient and nonnutrient components of legumes, and its chemopreventive activity: a review. Nutrition and Cancer, 67(3), 401-410. http://dx.doi.org/10.1080/01 635581.2015.1004729. PMid:25710272.

Sbroggio, M., Montilha, M., Figueiredo, V. G. D., Georgetti, S., \& Kurozawa, L. (2016). Influence of the degree of hydrolysis and type of enzyme on antioxidant activity of okara protein hydrolysates. Food 
Science and Technology (Campinas), 36(2), 375-381. http://dx.doi. org/10.1590/1678-457X.000216.

Sekhon, J., Grewal, S. K., Singh, I., \& Kaur, J. (2017). Evaluation of nutritional quality and antioxidant potential of pigeonpea genotypes. Journal of Food Science and Technology, 54(11), 3598-3611. http:// dx.doi.org/10.1007/s13197-017-2818-y. PMid:29051655.

Sharma, P., Kaur, H., Kehinde, B. A., Chhikara, N., Sharma, D., \& Panghal, A. (2020). Food-derived anticancer peptides: a review. International Journal of Peptide Research and Therapeutics

Singh, P. (2011). Antioxidant activity of food proteins and food protein hydrolysates (Master's thesis). Canada: McGill University.

Subagio, A. (2006). Characterization of hyacinth bean (Lablab purpureus (L.) Sweet) seeds from indonesia and their protein isolate. Food Chemistry, 95(1), 65-70. http://dx.doi.org/10.1016/j. foodchem.2004.12.042

Tang, C., Wang, X., \& Yang, X. (2009). Enzymatic hydrolysis of hemp (Cannabis sativa L.) protein isolate by various proteases and antioxidant properties of the resulting hydrolysates. Food
Chemistry, 114(4), 1484-1490. http://dx.doi.org/10.1016/j. foodchem.2008.11.049.

Thumbrain, D., Dwarka, D., Gerrano, A. S., \& Mellem, J. J. (2020). Antioxidant and apoptotic potential of protein isolates derived from Vigna unguiculata (L.) walp. International Journal of Food Science \& Technology, 55(7), 2813-2823. http://dx.doi.org/10.1111/ijfs.14535.

Torres-Fuentes, C., Contreras, M., Recio, I., Alaiz, M., \& Vioque, J. (2015). Identification and characterization of antioxidant peptides from chickpea protein hydrolysates. Food Chemistry, 180, 194-202. http://dx.doi.org/10.1016/j.foodchem.2015.02.046. PMid:25766818.

Udenigwe, C. C., \& Aluko, R. E. (2012). Food protein-derived bioactive peptides: production, processing, and potential health benefits. Journal of Food Science, 77(1), R71-24. http://dx.doi.org/10.1111/j.17503841.2011.02455.x. PMid:22260122.

Wang, H., Oo Khor, T., Shu, L., Su, Z.-Y., Fuentes, F., Lee, J.-H., \& Tony Kong, A.-N. (2012). Plants vs. cancer: a review on natural phytochemicals in preventing and treating cancers and their druggability. Anti-cancer Agents in Medicinal Chemistry, 12(10), 1281-1305. http://dx.doi. org/10.2174/187152012803833026. PMid:22583408. 